\title{
Molecular characterisation of new organisation of plnEF and p/w loci of bacteriocin genes harbour concomitantly in Lactobacillus plantarum I-UL4
}

Hui Fong Tai ${ }^{1}$, Hooi Ling Foo ${ }^{1,2^{*}}$, Raha Abdul Rahim ${ }^{2,3}$, Teck Chewn Loh ${ }^{4,5}$, Mohd. Puad Abdullah ${ }^{2,3,5}$ and Kimura Yoshinobu ${ }^{6}$

\begin{abstract}
Background: Bacteriocin-producing Lactic acid bacteria ( $L A B)$ have vast applications in human and animal health, as well as in food industry. The structural, immunity, regulatory, export and modification genes are required for effective bacteriocin biosynthesis. Variations in gene sequence, composition and organisation will affect the antimicrobial spectrum of bacteriocin greatly. Lactobacillus plantarum I-UL4 is a novel multiple bacteriocin producer that harbours both p/w and plnEF structural genes simultaneous which has not been reported elsewhere. Therefore, molecular characterisation of bacteriocin genes that harboured in L. plantarum I-UL4 was conducted in this study.

Results and discussion: Under optimised conditions, 8 genes (brnQ1, napA1, plnL, plnD, plnEF, plnl, plnG and plnH) of $p / n E F$ locus and 2 genes ( $p / w$ and $p / w G$ ) of p/w locus were amplified successfully from genomic DNA extracted from $L$. plantarum I-UL4 using specific primers designed from 24 pln genes selected randomly from reported plw, plS, pln423 and $p / n E F$ loci. DNA sequence analysis of the flanking region of the amplified genes revealed the presence of two $p / n$ loci, UL4-p/w and UL4-p/nEF loci, which were chromosomally encoded as shown by Southern hybridisation. UL4-p/w locus that contained three ORFs were arranged in one operon and possessed remarkable amino acid sequence of LMG2379-p/w locus, suggesting it was highly conserved. Interestingly, the UL4-p/nEF locus appeared to be a composite p/n locus of JDM1-p/nEF and J51-p/nEF locus in terms of genetic composition and organisation, whereby twenty complete and one partial open reading frames (ORFs) were aligned and organised successfully into five operons. Furthermore, a mutation was detected in plnF structural gene which has contributed to a longer bacteriocin peptide.

Conclusions: Plantaricin EF and plantaricin W encoded by plnEF and plnW loci are classified as class I bacteriocin and class II bacteriocin molecules respectively. The concurrent presence of two pln loci encoding bacteriocins from two different classes has contributed greatly to the broad inhibitory spectrum of L. plantarum I-UL4. The new genetic composition and organisation of p/nEF locus and concurrent presence of p/nEF and plnW loci indicated that L. plantarum I-UL4 is a novel multiple bacteriocin producer that possesses vast potentials in various industries.
\end{abstract}

Keywords: Molecular characterisation, Genetic organisation, Genetic location, pln genes, p/nEF locus, p/w locus, Bacteriocin gene, Lactobacillus plantarum I-UL4

\footnotetext{
*Correspondence: hlfoo@upm.edu.my

${ }^{1}$ Department of Bioprocess Technology, Faculty of Biotechnology

and Biomolecular Sciences, Universiti Putra Malaysia, 43400 UPM Serdang,

Selangor, Malaysia

Full list of author information is available at the end of the article
} 


\section{Background}

Lactic acid bacteria (LAB) is a group of bacteria frequently isolated from food. LAB genera that have important role in food and animal industries are Lactococcus, Leuconostoc, Pediococcus, Lactobacillus, and Streptococcus [1]. Extensive reports have shown LAB have capability to produce various compounds, such as acetic acid, hydrogen peroxide, ethanol, diacetyl and bacteriocins that contribute to the inhibitory effects to pathogenic microorganisms [2, 3]. Bacteriocins are ribosomal synthesised peptides or proteins that release extracellularly to inhibit bacteria closely related to the producing strains [4]. The inhibitory activities are mainly mediated through pore formation on cytoplasmic membrane or by inhibiting cell wall synthesis of sensitive bacteria [5-7]. Bacteriocins and bacteriocin-producing $\mathrm{LAB}$ have received special attention due to their potential applications in human and animal health, as well as in food industry [8-11]. The structural, immunity, regulatory, export and modification genes of bacteriocin that commonly arrange into one or more operon structures are required for effective bacteriocin biosynthesis $[12,13]$.

Despite a number of bacteriocins produced by Lactobacillus plantarum that generally known as plantaricin have been described [14-18], only a few plantaricin ( $p l n$; with italic formatted is used to describe gene) loci have been characterised genetically. The structure and organisation of $p \ln$ loci may be simple or complex. The relatively simple $p l n$ loci are found in one operon, such as $p l w$ locus that encodes Class I two-peptide plantaricin W [19], plS locus that encodes Class IIb plantaricin S [20] and pln 423 locus that encodes Class IIa plantaricin 423 [21]. The relatively complex $p \ln$ locus is $p \ln E F$ locus that distributes widely among $L$. plantarum isolated from various ecological niches. The well characterised $p \ln E F$ locus has been reported for L. plantarum C11 [22], WCFS1 [23], JDM1 [24], J23 [25], J51 [26], NC8 [27] and V90 [28]. The reported $p \ln E F$ loci have been designated as $p \ln E F$ locus for L. plantarum JDM1, C11, WCFS1, V90, J51, NC8 and J23 respectively. The size of the reported $p \ln E F$ loci are between 18 and $19 \mathrm{~kb}$ with 22 to 26 genes and they are organised in five to six operons in mosaic like structure encoding four types of class IIb plantaricins and three regulatory networks [28].

Probiotic effects of bacteriocin-containing postbiotic produced by $L$. plantarum have been reported for rats and livestock animals [29-34]. The bacteriocin-containing postbiotic of L. plantarum I-UL4 isolated from tapai ubi (fermented tapioca, a Malaysian traditional fermented food) has been shown to have broad inhibitory spectrum against various Gram-positive (Bacillus cereus, Staphylococcus aureus, Streptococcus pneumoniae, Enterococcus faecalis, Enterococcus faecium and Pediococcus acidilactici) and Gram-negative bacteria (Escherichia coli and Salmonella typhimurium) [35, 36]. According to Moghadam et al. [37], L. plantarum I-UL4 is a multiple bacteriocin producer that harbours both $p l w$ and $p \ln E F$ structural genes. The simultaneous detection of both $p l w$ and $p \ln E F$ that encode for plantaricin $\mathrm{W}$ and plantaricin EF respectively has not been reported elsewhere [37]. Furthermore, the genetic loci of $p \ln E F$ are in high plasticity and possess many variable regions with respect to their mosaic genetic composition and regulatory network [28]. Hence, the characterisation of $p l n$ loci is important as variations in gene sequence, gene composition and organisation will affect the antimicrobial spectrum of bacteriocin that release in extracellular environment. In addition, new open reading frame (ORF) can be discovered in close proximity to the known bacteriocin genes. Therefore, molecular characterisation of $p \ln E F$ and $p l w$ loci of bacteriocin genes that harbour concomitantly in Lactobacillus plantarum I-UL4 were conducted in this study.

\section{Results and discussion \\ pln genes of $L$. plantarum I-UL4}

The pln genes of L. plantarum I-UL4 were detected by PCR using gene-specific primers designed from 24 pln genes selected randomly from reported plw [19], plS [20], pln423 [21] and $p \ln E F[22,27]$ loci. Under optimised conditions, 8 genes (brnQ1, napA1, $\ln L, p \ln D$, $p \ln E F, p \ln I, p \ln G$ and $p \ln H)$ of $p \ln E F$ locus and 2 genes ( $p l w$ and $p l w G$ ) of $p l w$ locus were amplified successfully. The identities of amplified $p l n$ genes were further confirmed by DNA sequence analyses, whereby high DNA sequence identity (ranging from 96 to $100 \%$ ) that correspond to respective $p \ln$ gene was obtained for all amplified DNA fragments (Table 1). In contrast, 11 pln genes $(p \ln A, p \ln B, p \ln C, p \ln M, p \ln N, p \ln O, p \ln P, p \ln J, p \ln K$, $p l N C 8, p l N C 8 H K)$ of $p \ln E F$ loci and all the selected genes from $p l S$ and $p l n 423$ loci were absent in the studied strain as confirmed further by gradient PCR analysis, inferring that $L$. plantarum I-UL4 harbours $p l w$ and $p \ln E F$ loci simultaneously as reported by Moghadam et al. [37]. Although several studies reported the presence of $p \ln E F$ gene in bacteriocinogenic L. plantarum isolated from fermented foods by PCR screening, none of the reported isolates harboured $p l w$ structural gene [38-40] simultaneously. In addition, only $p \ln E F$ structural gene was found in the complete genome sequence of $L$. plantarum WCFS1 [23] and L. plantarum JDM1 [24]. Therefore, $L$. plantarum I-UL4 is the first $L$. plantarum strain that has been reported to harbour both $p l w$ and $p \ln E F$ structural genes concomitantly, which have contributed greatly to the broad inhibitory spectrum of bacteriocin-containing postbiotic produced by $L$. plantarum I-UL4 against 
Table 1 Nucleotide sequence characteristics of PCR-amplified pln genes harboured in Lactobacillus plantarum I-UL4 in comparison to the pln genes reported for Lactobacillus plantarum JDM1, C11, WCFS1, V90, J51, NC8, J23 and LMG2379

\begin{tabular}{|c|c|c|c|c|c|c|c|c|c|c|}
\hline \multirow[t]{2}{*}{ pln genes } & \multirow[t]{2}{*}{ Length (bp) } & \multirow[t]{2}{*}{ Function of gene } & \multicolumn{8}{|c|}{ Nucleotide sequence identity (\%) } \\
\hline & & & JDM1 & C11 & WCFS1 & V90 & J51 & NC8 & $J 23$ & LMG2379 \\
\hline brnQ1 & 1,088 & Amino acid transport protein & 98 & ND & 98 & ND & 98 & ND & 99 & ND \\
\hline napA1 & 738 & $\mathrm{Na}^{+} / \mathrm{H}^{+}$antiporter & 98 & ND & 99 & ND & 99 & 99 & 98 & ND \\
\hline$p \ln L$ & 382 & Putative immunity protein & 96 & 96 & 96 & 96 & 96 & 96 & 96 & ND \\
\hline plnD & 365 & Response regulator & 100 & 96 & 96 & 95 & 96 & 100 & 96 & ND \\
\hline plnl & 558 & Immunity & 98 & 98 & 98 & 98 & 98 & 98 & 99 & ND \\
\hline plnEF & 369 & Prebacteriocin & 98 & 99 & 99 & 98 & 99 & 99 & 99 & ND \\
\hline$p \ln G$ & 394 & $\mathrm{ABC}$ transporter & 99 & 99 & 99 & 98 & 99 & ND & 99 & ND \\
\hline plnH & 926 & Accessory protein & 99 & 98 & 98 & 98 & 98 & ND & 98 & ND \\
\hline plw & 279 & Prebacteriocin & ND & ND & ND & ND & ND & ND & ND & 100 \\
\hline plwG & 975 & ABC transporter & ND & ND & ND & ND & ND & ND & ND & 99 \\
\hline
\end{tabular}

ND not detected, the respective gene was not detected in the reference strain.

various Gram-positive (Bacillus cereus, Staphylococcus aureus, Streptococcus pneumoniae, Enterococcus faecalis, Enterococcus faecium and Pediococcus acidilactici) and Gram-negative bacteria (Escherichia coli and Salmonella typhimurium) as reported by Lim [35] and Thanh et al. [36]. Moreover, the $p \ln$ genes in plnEF locus of L. plantarum I-UL4 [UL4-plnEF locus; for simplicity, the ORF, peptide or locus of a strain was abbreviated as (name of the strain)-(ORF, peptide or locus)] were different from the reported $p \ln E F$ loci.

\section{Characterisation of UL4-p/w locus}

The upstream and downstream DNA sequences of plw and $p l w G$ were amplified and analysed from genomic DNA of L. plantarum I-UL4 (plw loci of L. plantarum I-UL4 were deposited at GenBank/EMBL/DDBJ with accession number of GU322921). A contig of $2.77 \mathrm{~kb}$ termed UL4-plw locus was successfully assembled and DNA sequence analysis of UL4-plw locus revealed the presence of three ORFs ( $p l w \beta$, plw $\alpha$ and $p l w G$ ) that arranged in one operon with same orientation. Both $p l w \beta$ and $p l w \alpha$ were $100 \%$ identical to LMG2379-plw $\beta$ and LMG2379-plw $\alpha$ respectively [19]. $p l w \alpha$ and $p l w \beta$ are the structural genes that encode for Class I two-peptide lantibiotic, plantaricin $\mathrm{W}$, whereby the mature peptides are modified to contain lanthionine, methyl Lanthionine and dehydrated residues [19]. The last ORF, plwG, that encoded for $\mathrm{ABC}$-transporter was highly similar (more than $99.7 \%$ identities) to LMG2379-plwG [19].

\section{Characterisation of UL4-pInEF locus}

The upstream and downstream DNA sequences of brnQ1, napA1, $\ln L, p \ln D, p \ln E F, p \ln I, p \ln G$ and $p \ln H$ in $p \ln E F$ locus were successfully amplified and sequenced from genomic DNA of $L$. plantarum I-UL4 and a contig of $17.58 \mathrm{~kb}$ that designated as UL4-plnEF locus was obtained by careful alignment and assembly ( $p \ln E F$ loci of L. plantarum I-UL4 were deposited at GenBank/ EMBL/DDBJ with accession number of GU138149). The amino acid sequence of deduced peptides encoded by UL4-plnEF locus and the reported plnEF loci are shown in Table 2. Figure 1 shows the putative promoters that were searched manually by sequence alignment and comparison to the promoter sequences reported for $p l n$ operons. The promoter sequences that identified in the UL4-plnEF locus were consisted of a pair of direct repeat which was located at the upstream of -35 region. Each pair of the repeats was separated by a spacer of 12 nucleotides that rich in adenine and thymine. The characteristic of promoters identified in UL4-plnEF locus were highly identical to the reported $p \ln E F$ loci [28]. The direct repeat pair is important for the regulation of bacteriocin biosynthesis at transcriptional level as this consensus direct repeat serves as DNA binding sites for response regulator $(R R)$ to initiate the transcription process [41, 42]. Changes in nucleotide sequence of the repeat such as point substitutions, deletion of repeat or alteration in the length of spacer region can abolish or reduce the binding of RR and subsequently suppress the gene expression [43]. The promoter motifs of $p l n$ operons were also found in other bacteriocin systems such as gene cluster of sakacin A [44, 45], sakacin P [46, 47], carnobacteriocin A [48], carnobacteriocin B2 [49] and enterocin A [50, 51], indicating similar regulatory mechanism was used for the production of various bacteriocins.

Biocomputational analyses of UL4-plnEF locus revealed the presence of 20 complete and one partial ORFs. The comparison of genetic organisation of UL4$p \ln E F$ locus and reported $p \ln E F$ loci are illustrated in a genetic map as shown in Figure 2. Five putative operons 
Table 2 Characteristics of the predicted ORFs encoded by UL4-pInEF locus amplified from Lactobacillus plantarum I-UL4

\begin{tabular}{|c|c|c|c|c|c|c|}
\hline $\begin{array}{l}\text { Predicted } \\
\text { ORFs }\end{array}$ & $\begin{array}{l}\text { Orienta- } \\
\text { tion } \\
(+ \text { or }-)\end{array}$ & $\begin{array}{l}\text { Nucleotide } \\
\text { coordinates }\end{array}$ & $\begin{array}{l}\text { Gene and } \\
\text { peptide } \\
\text { length (bp: aa) }\end{array}$ & $\begin{array}{l}15 \text { bp upstream of the } \\
\text { start codon }\left(5^{\prime}-3^{\prime}\right)\end{array}$ & $\begin{array}{l}\text { Homologous gene } \\
\text { and function }\end{array}$ & Re-designated as \\
\hline ef1 & + & $829-2,205$ & $1,377: 458$ & GGAGGAGAGACGACT & $\begin{array}{l}\text { brnQ1: amino acid } \\
\text { transporter }\end{array}$ & brnQ1 \\
\hline ef2 & + & $2,238-3,434$ & 1,197: 398 & TAAGACTTTTGATGG & $\begin{array}{l}\text { napA1: } \mathrm{Na}^{+} / \mathrm{H}^{+} \\
\text {antiporter }\end{array}$ & napA1 \\
\hline ef3 & + & $3,809-3,982$ & 174: 57 & GAAAAGGTGATTAAA & $\begin{array}{l}\text { orf3: putative prebac- } \\
\text { teriocin }\end{array}$ & orf3 \\
\hline ef4 & + & $3,998-4,177$ & 180: 59 & AAAGAAGTGGTAAAA & $\begin{array}{l}\text { orf4: putative prebac- } \\
\text { teriocin }\end{array}$ & orf4 \\
\hline ef5 & + & $4,283-4,525$ & 243: 80 & TTGTTTGTTCTTTTA & $\begin{array}{l}\text { orf5: putative immu- } \\
\text { nity protein }\end{array}$ & orf5 \\
\hline ef6 & - & $4,970-5,083$ & $114: 37$ & GTAAGGCACACGTTA & plnR: unknown & $p \ln R$ \\
\hline ef7 & - & $5,108-5,776$ & 669: 222 & CTCGGGGGATTATAA & $\begin{array}{l}\text { plnL: putative immu- } \\
\text { nity protein }\end{array}$ & plnL \\
\hline ef8 & + & $6,369-6,536$ & 168: 55 & $\underline{\text { GGAGGGGTTATTATT }}$ & $\begin{array}{l}\text { Putative induction } \\
\text { factor }\end{array}$ & ULAIF \\
\hline efg & + & $6,554-7,894$ & 1,341: 446 & TAGGTGGTGTTCCAC & $\begin{array}{l}\text { HK: histidine Protein } \\
\text { Kinase }\end{array}$ & UL4HK \\
\hline ef10 & + & $7,895-8,638$ & 744: 247 & TTGGAGGAAGAATGA & $\begin{array}{l}\text { plnD: response } \\
\text { regulator }\end{array}$ & $p \ln D$ \\
\hline ef11 & - & $8,932-9,705$ & $774: 257$ & GGGGGAATTTTAACT & plnl: immunity protein & plnl \\
\hline ef12 & - & $9,784-9,963$ & 180: 59 & GGGAGATCAACAATT & $\begin{array}{l}\text { plnF: plantaricin EF } \\
\text { precursor }\end{array}$ & $p \ln F$ \\
\hline ef13 & - & $9,988-10,158$ & $171: 56$ & CAAGGGGGATTATTT & $\begin{array}{l}\text { plnE: plantaricin EF } \\
\text { precursor }\end{array}$ & plnE \\
\hline ef14 & + & $10,424-12,574$ & $2,151: 716$ & GAGGGGAGTACAAGT & plnG: $A B C$ transporter & $p \ln G$ \\
\hline ef15 & + & $12,591-13,967$ & $1,377: 458$ & GGGGGAAACTGAATA & $\begin{array}{l}\text { plnH: accessory } \\
\text { protein }\end{array}$ & plnH \\
\hline ef16 & + & $14,057-14,746$ & 690: 229 & CGAAAGAGGTAAGTA & plnT: unknown & $p \ln T$ \\
\hline ef17 & + & $14,814-15,482$ & 669: 222 & CTTGGGAGGCTTGGT & plnU: unknown & $p \ln U$ \\
\hline ef18 & + & $15,569-16,249$ & $681: 226$ & TGGATGTGAAGGAGC & plnV: unknown & $p \ln V$ \\
\hline ef19 & + & $16,343-17,029$ & $687: 228$ & GATGGAGTGGATGAA & plnW: unknown & $p \ln W$ \\
\hline ef20 & + & $17,167-17,370$ & $204: 67$ & AGGAGTTTGGTAAGT & orfZ1: unknown & UL4orfZ1 \\
\hline ef21 & - & $17,465->17,588$ & $>124:>40$ & ND & $\begin{array}{l}\text { DHelicase: DNA } \\
\text { helicase }\end{array}$ & DHelicase \\
\hline
\end{tabular}

Underlined nucleotides are putative RBS. No RBS could be detected for ef5 which was re-designated as plnR. ef 8 did not show homology to any entries in database but the deduced peptide sequence contained GG motif. ef 21 was partially sequenced and hence upstream sequence of ef 21 is not available.

ND not detected.

(orf345, plnLR, UL4IF-UL4HK-plnD, plnEFI and $p \ln G-$ $H T U V W)$ that preceded by a putative promoter were deduced from the UL4-plnEF locus. The operons of orf345, $\ln L R$ and $p \ln E F I$ were predicted to encode for a two-peptide bacteriocin and immunity protein respectively. The ULAIF-UL4HK-plnD operon was predicted to regulate bacteriocin production at transcriptional level. The last predicted operon, $p \ln G H T U V W$, was responsible for maturation and secretion of bacteriocins and bacteriocin-like peptides as proposed by Diep et al. [22, 28]. Three ORFs of brnQ1, napA1 and DHelicase that amplified and sequenced from the genomic DNA of L. plantarum I-UL4 were also found in the reported operons.
However, their functions have not been related to any bacteriocin production.

Three-component regulatory system of ULAIF$U L 4 H K-p \ln D$ was detected in the UL4-plnEF locus as compared to $p \ln A B C D$ or $p l N C 8 I F-p l N C H K-p \ln D$ regulatory operon that reported for $p \ln E F$ locus by Diep et al. [28]. UL4IF was found to encode a putative induction factor (IF) that usually activates transcription process of regulated genes. The leader peptide of UL4IF contained a double-glycine (GG) motif and the mature peptide consisted of 28 amino acids. The calculated pI and the MW of the mature peptide was 11.26 and $3321.98 \mathrm{Da}$, respectively. The IFs that identified in bacteriocin 


\begin{tabular}{|c|c|c|c|c|c|c|c|c|}
\hline Operon & $\underline{\text { strain }}$ & & $\underline{L}$-repeat & & $\underline{\mathrm{R}}$-repeat & -35 & -10 & \\
\hline orf 345 & UL4 & GIGGTATCGGTGAATTATTG & TATGATAAT & AGCTAAAAATAT & GACGTTTGT & CGTTCG ATAGGICGGGTGGGIGI & I TATATT & T AAGAGCATAGAAA \\
\hline oxf 345 & J51 & GIGGTAICGGTAAATTATIG & TACGATAAT & AGCTAAAAATAI & GACGTTIGI & CGTTCG ATAGGICGGGTAGGIGI & I TATATT & T AAGAGCATAGAAA \\
\hline IR & JDMI & ATGGCCCTCACTITCAAAAT & TACGTTAAG & ICGGGIGAATAG & TATATTAAT & AAATTTAAAA ATGATT TITITAGAATTGTAGTG & G TATCTT & T AATAAATGTAC \\
\hline JKLR & C11 & CAGACAITCAACITTCAAGT & TACGTTAAA. & ICGATTAAATAG & TACGATAAC & AAATTTAAA ATAATT TTTITTAAATTGTAGCG & G TATATT & T AATAAGTGCATT \\
\hline JKLR & WCES1 & CAGACATTCAACITTCAAGT & TACGTTAAA & TCGATTAAATAG & TACGATAAC & ATAATT TITTTTAAATTGTAGCG & G TATATT & T AATAAGTGCATT \\
\hline JKLR & v90 & CAGACAITCAACTTICAAGT & TACGTTAAA & TCGATTAAATAG & TACGATAAC & ATAATT TITTTIAAATTGTAGCG & G TATATT & T AATAAGTGCATT \\
\hline LR & $\mathrm{J} 51$ & CAGATATTCAATCTAAAAGT & TACGTTAAG & TCGAGIGAATAG & TACGATAAT & AAATTTAAAA ATGATT TITITAGAATTGTAGTG & G TATCTT & T AATAAAAGTAC \\
\hline JLR & J23 & CGGACACTCAATCTAAAAGT & TACGTTAAA & TCGETTAAATAG & TACGATAAC & ATAATT TTTTGAATTGTAGCG & TATATT & T AATAAGTGTATT \\
\hline IF-HK-D & UL4 & TIACAATATAAATGAACATT & AACGTTAAA. & ACTATATAATTT & AACGITAAT & ACTTGATT TTGCAA AAATATTGATAATCATGT & TAAGTT & TACAGATAAGGAG \\
\hline plnABCD & C11 & GTTGGAATTTCATGGTGATT & CACGTTTAA & ATTTAAAAAATG & TACGTTAAT & AGAAATAA TTCCTC CGTACTTCAAAAACACAT & TATCCT & AAAAGCGAGGTG \\
\hline plnABCD & 351 & GTGGAAATTTTATGIT GATT & CACGTTTAA & ATTCAAAAAATG & TACGTTAAT & AGAAATAA TOCCAG CGTACCTCAAAAACACCT & TATCCT & AAAAGCGAGGTG \\
\hline plNC8IF & $\mathrm{J} 23$ & ACAATIGTATIGAATAGCGA & GACGTTTAT & AGCACITITATG & TACGTTAAT & GAAGTAAC GTAATT GGAGTAGAAAATATAAGG & TATCCT & AGTATITGGAGG \\
\hline plNC8IF & NC8 & ACAATTGTATIGAATAGTGT & GACGTTTAT & AGCACTTITATE & TACGTIAAT & GAAGTAAC GTAATT GGAGTAGAAAATATAAGG & TATCCT & AGTATITGGAGG \\
\hline EFI & UL4 & ACTAGCTAGCATTGGTATTT & GACGTTAAG & AGAACETTTTTI & TACTTTTAT & AATTTTT TCAACA ATCTGGTAAAAAATAAAT & TAAACT & AAATTIGTTTCA \\
\hline EFI & JDM & ACTAGCTAACATTGGTATTT & GACGTTAAG & AGAACETTTITI & TACTTTTAT & AATTTTI TCAACA ATCTC & TAAACT & AAATITGTTCCA \\
\hline EFI & WCES1 & ACTAGCTAACATTGGTATTT & GACGTTAAG & AGAACGTTTTTI & TACTTTTAT & AATTTTI TCAACA ATCTGGTAAAAAAATAAAT & TAAACT & AAATITGTTCCA \\
\hline EFI & v9o & ACTAGCTAACATIGGTATTT & GACGTTARG & AGAACGTITITI & TACTTTTAT & AAITTTI TCAACA ATCTGGTAAAAAAATAAAT & TAAACT & AAATITGITCCA \\
\hline EFI & NC8 & ACTAGCTAACATIGGTATTT & GACGTTAAG & AGAACGITTITI & TGCTTTAAT & AAITTTI TCAACA ATCTGGTAAAAAAATAAAT & TAAACT & AAATITGITCCA \\
\hline EFI & $\mathrm{J} 51$ & ACTAGCTAACATTGGTATTT & GACGTTAAG & AGAACGTTTTTI & TACTTTTAT & AAITTTT TCAACA ATCTGGTAAAAAAATAAAT & TAAACT & AAATITGTTCCA \\
\hline EFI & J23 & ACTAGCTAACATTGGTATTT & GACGTTAAG & AGAACGTTTTTI & TACTTTTAT & AATTTTI TCAACA ATCTGGTAAAAAAATAAAT & TAAACT & AAATITGITCCA \\
\hline GHTUVW & UL4 & TAACCGITAAGCCTGATGAG & TTCAT & CGTAAGATTATG & TACGTTAAT & AGATAG TTGGCA TACG & CATAAT & ACTG \\
\hline GHTUVN & JDMI & TAACCGITAAGCCTGATGAG & GACATTTAT & CATAAAATTATG & TACGTTAAT & AGATAG TTGGCA TACGATAACATTTGTTAGCC & CATAAT & TAAATAGATACC \\
\hline GHSTUVW & C11 & TAACCGITAAGCCTGATGAG & GACATTTAT & CATAAAATTATG & TACGITAAT & AGATAG TTGGCA TACGATAACATTTGTTAGCC & CATAAT & TAAATAGATACC \\
\hline GHSTUVW & WCFS1 & TAACCGITAAGCCTGATGAG & GACATTTAT & CATAAAATTATG & TACGTTAAT & AGATAG TTGGCA TACGATAACATTTGTTAGCC & CATAAT & TAAATAGATACC \\
\hline GHTUVWT & v9o & TAACCGITAAGCCTGATGAG & GACATTTAT & CATAAAATTATG & TACGTTAAT & AGATAG TTGGCA TACGATAACATITGTTAGCC & CATAAT & TAAATAGATACC \\
\hline GHSTUNW & J51 & TAACCGITAAGCCTGATGAG & GACATTTAT & CATAAAATTATG & TACGTTAAT & AGATAG TTGGCA TACGATAACATTTGTTAGCC & CATAAT & TAAATAGATACC \\
\hline GHSTUVW & NC8 & TAACCGITTAGCCTGATGAG & GACATTTAT & CAAAAAATTATG & TACGTTAAT & AGATAG TTGGCA TACGATAACATTTGTTAGCC & CATAAT & TAAATAGATACC \\
\hline GHSTUNN & $\mathrm{J} 23$ & TAACCGTTAAGCCTGATGAG & GACATTTAT & CATAAAATTATG & TACGTTAAT & AGATAG TTGGCA TACGATAACATTTGTTAGCC & CATAAT & TAAATAGATACC \\
\hline \multicolumn{3}{|c|}{ Core consensus } & TACGTTAAT & $\ldots \ldots 12 \ldots \ldots$ & TACGTTAAT & TTGACG & TATAAT & \\
\hline
\end{tabular}

Figure 1 Putative promoters of UL4-pInEF locus that searched by DNA sequence alignment and comparison to the promoter sequences reported for pInEF loci. The promoters that identified in UL4-pInEF locus were consisted of a pair of direct repeat which was located at the upstream of - 35 region. Each pair of the repeats was separated by a spacer of 12 nucleotides that are highlighted in grey-boxes. Putative -35 and -10 sequences are indicated with boldface.

systems are a small bacteriocin-like peptide having several physicochemical properties of bacteriocin. Both IF and bacteriocin are synthesised as a precursor peptide containing GG leader peptide and hence the same maturation and secretion system has been suggested for both IF and bacteriocin. In addition, the mature peptide of both IF and bacteriocin has high pI and low MW. Although IF and bacteriocin share several physicochemical properties, IF can be discriminated from bacteriocin in the way that IF possess little or no bacteriocin activity and the gene encoding IF is always located in the same transcription unit and preceded the gene encoding histidine protein kinase (HPK) and RR [47, 48, 50, 52, 53]. $U L 4 H K$ that encoded for HPK and $p \ln D$ that encoded for RR were located at downstream and in the same transcriptional unit of ULAIF. DNA sequence alignment of UL4HK with HPK of reported plnEF loci revealed low amino acid sequence identities at $\mathrm{N}$-terminal receptor domain of HPKs (Figure 3). On the contrary, the C-terminal domain of HPKs shared significant nucleotide and amino acid sequence identity. Nevertheless, the regulatory operons of the reported $p \ln E F$ loci were semiconserved in which $p \ln D$ was found in all regulatory operons regardless of the HPK type, suggesting that the interaction between IF and HPK is highly specific while the interaction between HPK and RR is less specific. The results obtained in this study were further supported by the notion of antimicrobial activity of $L$. plantarum J23 containing plNC8IF-plNCHK-plnD regulatory operon that only could be detected when induced by plNC8IF and not $\operatorname{pln} \mathrm{A}$ [25].

The plnEFI operon encoded for plantaricin EF and its cognate immunity protein was present in L. plantarum I-UL4. No variation of amino acid was detected in UL4plnE as compared to the reported plnE. However, UL4$p \ln F$ was seven amino acids longer than the reported plnF peptide due to the insertion of two nucleotides at the stop codon resulting in additional translation of seven amino acids $\mathrm{N}^{\prime}$ - YSSSHQV- $\mathrm{C}^{\prime}$ prior to TAA stop codon (Figure 4). Thus, the mature UL4-plnF contains 41 amino acids with the calculated MW of $4.492 \mathrm{kDa}$, as compared to 34 amino acids of the reported plnF. The pI of UL4-plnF is 9.99 which is 0.28 unit lower than the plnF of the reported $p \ln E F$ loci. A similar case was demonstrated by Rojo-Bezares et al. [25] for J23-plnJ, whereby J23-plnJ was reported to be 28 amino acids longer than the reported plnJ (55 amino acids) and a great reduction in antimicrobial activity was observed in the J23-plnJ 


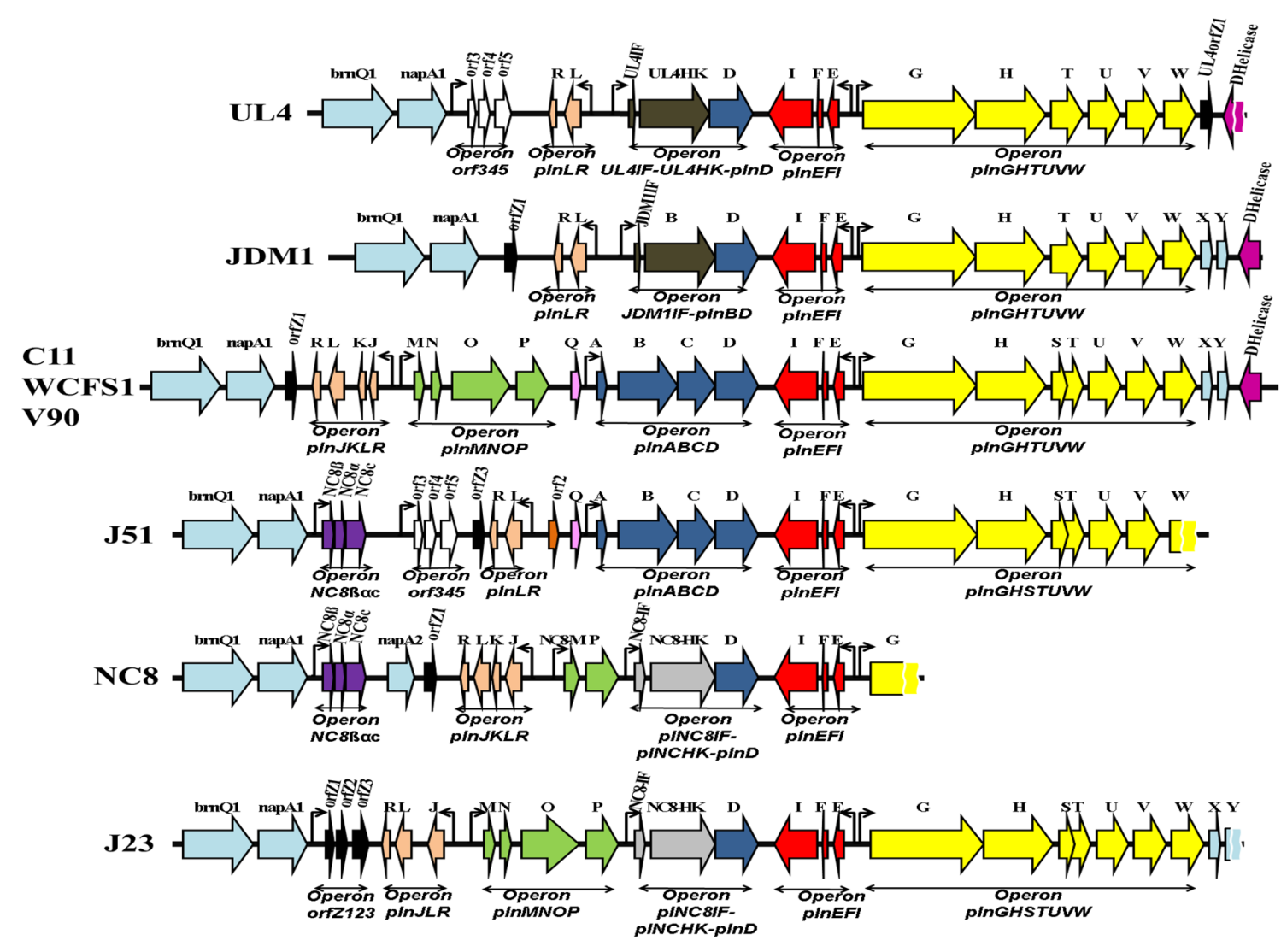

Figure 2 Genetic map for the comparison of genetic organisation of UL4-pInEF locus and reported plnEF loci of L. plantarum strains. ORFs are represented by arrow-blocks. The promoter sequences are indicated by small black arrows. brnQ1 and napA1 signify the upper boundary while DNA helicase signify the lower boundary of plnEF loci. The DNA sequence of UL4-DHelicase, J51-plnW, NC8-plnG and J23-plnY was partially analysed. C11-, WCFS1- and V90-pInEF loci were identical. However, brnQ1, napA1, plnX, plnY and DHelicase were not described in C11; brnQ1, napA1 and DHelicase were not described in V90; plnS and plnT were "fused" in V90. The genetic map was generated using information retrieved from GenBank with accession number of CP001617 (JDM1), X94434 (C11), NC_004567 (WCFS1), FJ809773 (V90), DQ340868 (J51), AF522077 (NC8) and DQ323671 (J23) respectively.

peptide. However, the antimicrobial activity of the UL4plnF has yet to be determined.

Another bacteriocin-like operon orf345 that previously described in L. plantarum J51 [26] was detected in UL4plnEF locus as well. Operon UL4-orf345 contained three ORFs of orf3, orf4 and orf5, which was highly identical to those described for L. plantarum J51. However, one amino acid mismatch was detected in both orf3 and orf4 [26] respectively and GG leader peptide was detected in both UL4-orf3 and UL4-orf4 [54]. The mature peptide of UL4-orf3 and UL4-orf4 has highly cationic property with calculated pI of 11.45 and 9.87 respectively. Hence, UL4orf345 operon resembles a bacteriocin and immunity operon encodes for a two-peptide bacteriocin together with its cognate immunity protein.

A class II bacteriocin, plantaricin JK together with its dedicated immunity and a hypothetical protein with unknown function were encoded by $p \ln J K L R$ operon [22]. The $p l n J K L R$ operon was found as a degenerated operon, $p \ln L R$, in the UL4- $p \operatorname{lnEF}$ locus. In addition, similar degenerated form of $p \ln J K L R$ operon was reported commonly in $p \operatorname{lnEF}$ loci in the form of $p \ln J L R$ or $p \ln L R$ operon [28].

UL4-orfZ1 showed high nucleotide sequence identity to orfZ1 of L. plantarum JDM1, C11, WCFS1, V90, NC8 and J23. The orfZ1 is the member of putative bacteriocinlike operon, namely orfZ123 operon, which consists of three ORFs. The orfZ2 was reported to encode a peptide with GG motif leader peptide, while the orf $Z 1$ and the orfZ3 were encoded for peptides with unknown functions [25]. However, the degenerated form of orfZ123 operon (orfZ1 alone) was detected in L. plantarum I-UL4. According to Diep et al. [28], this operon was degenerated greatly, whereby either orfZ1 or orfZ3 was detected in the reported $p \ln E F$ loci. 


\begin{tabular}{|c|c|c|}
\hline UL4 & HK & MLDFGVVDTFYQGFTSVLVVLLWYYFLSGLFNWKSVLKILVLTFFWGVLSVFVADFILLIMVLINFASQFIQKKSLNYDK 80 \\
\hline JDM1 & $\mathrm{plnB}$ & 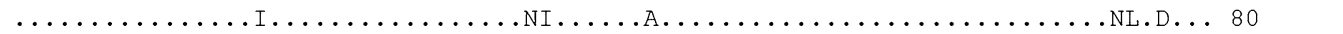 \\
\hline C11 & $\mathrm{plnB}$ & LVEISIF.SVI.S.FIY.GII.V.N.IFSNT.I.RIIYS.I.LLVLSLVGAILD.TTS..L..GAIIKEKC.P-KI..YH 79 \\
\hline WCES1 & $1 \mathrm{plnB}$ & LVEISIF.SVI.S.FIY.GII.V.N.IFSNT.I.RIIYS.I.LLVLSLVGAILD.TTS..L..GAIIKEKC.P-KI..YH 79 \\
\hline V90 & plnB & LVEISIF.SVI.S.FIY.GII.V.N.IFHNTSI..IIYS.I.LLVLSLVGAILD.TTS. .L. .GAVIKEKC.P-KI..YN 79 \\
\hline J51 & plnB & LVEISIF.SVI.S.FIY.GII.V.N.IFSNT.I.RIIYS.I.LLVLSLVGAILD.TTS..L..GAIIKEKCRP-KI. .YH 79 \\
\hline J23 & plnc8K & ..SIEFT.A....SVCFFTI.V...Y.I.AL.KRALVRVI.MSLLL.AG....S.ISY..V.AAVMVG.I.RYHR.D.AR 80 \\
\hline NC8 & plnc8K & ..SIEFT.A....SVCFFTI.V...Y.I.AL.KRALVRVI.MSLLL.AG....S.ISY..V.AAVMVG.I.RYHR.D.AR 80 \\
\hline UL4 & $\mathrm{HK}$ & SGILLLVVI IQVLIGNIAMFLGRMSVRGLYNVSNLMGVQYYTHEVLI IYVIFVII INYAILFFYRRYCHKIVSVNRKIKE 160 \\
\hline JDM1 & $\mathrm{p} \ln B$ & 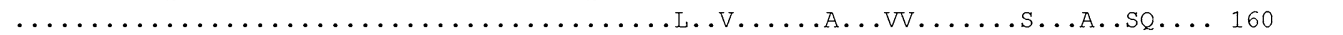 \\
\hline C11 & $\mathrm{pln} B$ & LNVF.MLISS.IV.LAL.SY.S.GFLYIYLDADKIS.LSE.GDLFIG.EI.VMY..GFLVFNLVYKMVRRYTGSFDISDD 159 \\
\hline WCES1 & $1 \mathrm{pln} B$ & LNVF.MLISS.IV.LAL.SY.S.GFLYIYLDADKIS.LSE.GDLFIG.EI.VMY..GFLVFNLVYKMVRRYTGSFDISDD 159 \\
\hline V90 & $\mathrm{p} \ln \mathrm{B}$ & LNVF.MLISS.IV.LAL.SY.S.GFLYIYLDADKIS.LSE.GDLFIG.EI.VMY..GFLV.NLVYKMVRRYTDSFDISDD 159 \\
\hline J51 & $\mathrm{pln} B$ & LNVF.MLISS.IV.LAL.SY.S.GFLYIYLDADKIS.LSE.GDLFIG.EI.VMY..GFLVFNLVYKMVRRYTGSFDISDD 159 \\
\hline J23 & plnc $8 \mathrm{~K}$ & .S.MIFL.N...IMS . LLVYTS.WIILCA.GTTSEQRIYH.G.M.VLC..VVMG.M.AL.ISLMKK.SSE.NAMID ..Y 160 \\
\hline NC8 & plnc8K & .S.MIFL.N...IMS ..LVYTS.WIILCA.GTTSEQRIYH.G.M.VLC..VVMG.M.AL.ISLMKK.SSF.NAMID ..Y 160 \\
\hline UL4 & HK & LNLSKSLFELILIFYVAIESIMLISLNENITATIQLTLITSFIVMLLMMLWQMFFFIRSYMKKQEASYQAKQNTQLNEYL 240 \\
\hline JDM1 & plnB & 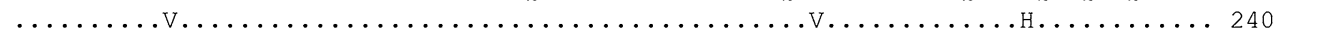 \\
\hline C11 & plnB & 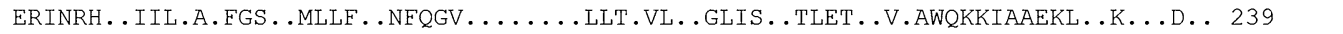 \\
\hline WCFS1 & $1 \mathrm{plnB}$ & ERINRH . .IIL.A.FGS . MLLF . NFFQGV . . . . . . . LLLT.VL . .GLIS . .TLET . V.AWQKKIAAEKL . K . . D . 239 \\
\hline V90 & $\mathrm{pln} B$ & 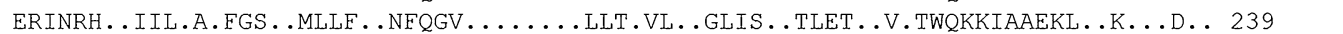 \\
\hline J51 & $\mathrm{p} \ln \mathrm{B}$ & 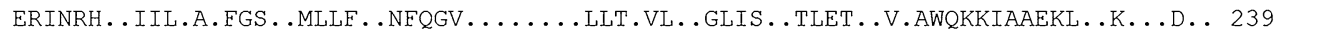 \\
\hline J23 & plnc8K & 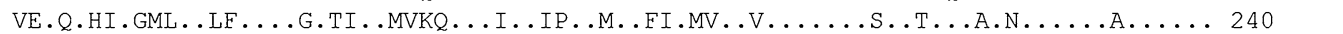 \\
\hline $\mathrm{NC} 8$ & plnc $8 \mathrm{~K}$ & 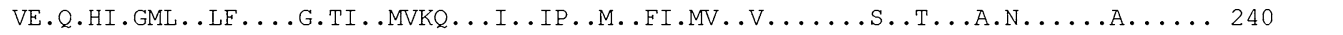 \\
\hline UL4 & HK & KSVEQQYLELRRFKHDYKNVMLALQDSISSGSSSEQLPYFKELIAQSAIDTSLDSGKIAKIQHVGNETLRGLIVQKFFDA 320 \\
\hline JDM1 & $\mathrm{p} \ln \mathrm{B}$ & 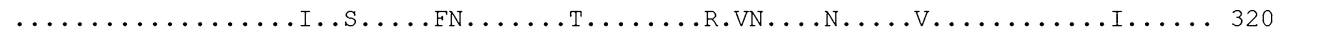 \\
\hline C11 & $\mathrm{p} \ln \mathrm{B}$ & 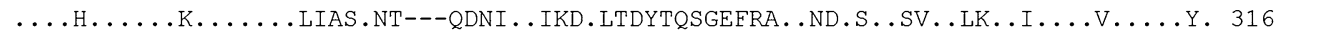 \\
\hline WCFS1 & $1 \mathrm{pln} B$ & 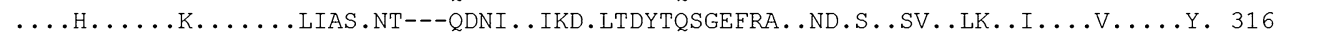 \\
\hline V90 & plnB & 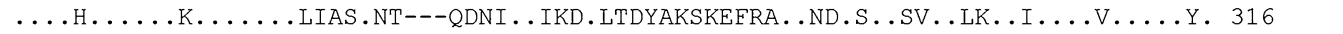 \\
\hline J51 & $\mathrm{pln} B$ & 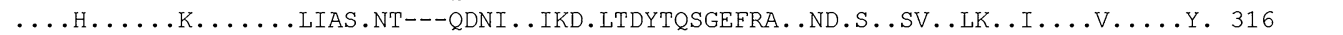 \\
\hline J23 & plnc8K & 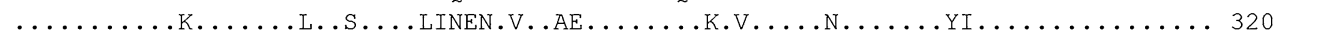 \\
\hline NC8 & plnc8K & 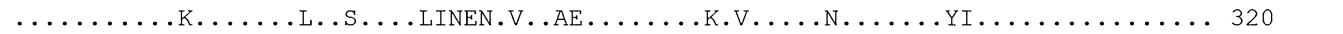 \\
\hline UL4 & HK & QTKGIELSLELDQSEFI IQHNLVDVVRIVGNLLDNAIDAAKSTPDKQVTCAFNSLHETKEISVRNSTNKKLDVNKMFELG 400 \\
\hline JDM1 & plnB & 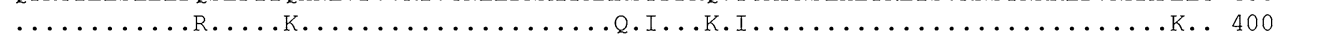 \\
\hline C11 & $\mathrm{p} \ln \mathrm{B}$ & 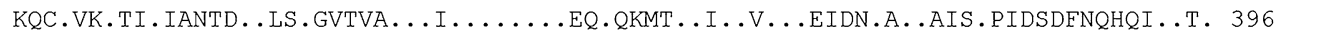 \\
\hline WCES1 & $1 \mathrm{pln} B$ & 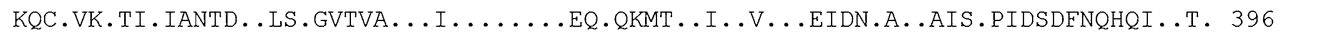 \\
\hline V90 & $\mathrm{p} \ln \mathrm{B}$ & 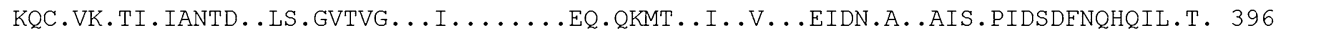 \\
\hline J51 & $\mathrm{p} \ln \mathrm{B}$ & 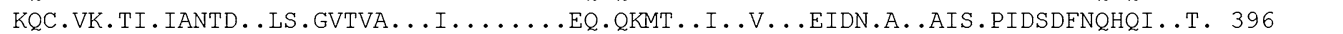 \\
\hline J23 & plnc8K & 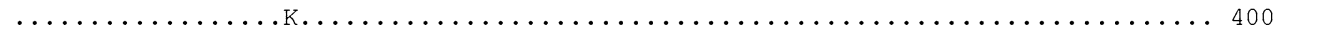 \\
\hline NC8 & plnc8K & 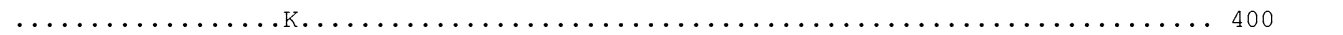 \\
\hline UL4 & HK & ASTKGSQRGFGLSNVQQLVDKQKNFFLDVDSKNDRVI ITLTILEEE 446 \\
\hline JDM1 & $\mathrm{p} \ln \mathrm{B}$ & $\ldots \ldots \ldots+\ldots \ldots \ldots \ldots \ldots \ldots \ldots, \ldots \ldots \ldots, 446$ \\
\hline C11 & $\mathrm{p} \ln \mathrm{B}$ & Y.....N..L..T. .RD..EQ..G.YM.IET.KNY.TM..IVT.DK 442 \\
\hline WCES1 & $1 \mathrm{pln} B$ & Y.....N..L..T.RR..EQ..G.YM.IET.KNY.TM..IVT.DK 442 \\
\hline V90 & $\mathrm{p} \ln \mathrm{B}$ & Y.....N..L..T..RD...Q..G.YM.IET.K.Y.TM..IVT.DK 442 \\
\hline J51 & $\mathrm{p} \ln \mathrm{B}$ & Y.....N..L..T..RD..EQ..G.YM.IET.KNY.TM..IVT.DK 442 \\
\hline $\mathrm{J} 23$ & plnc8 $\mathrm{K}$ & 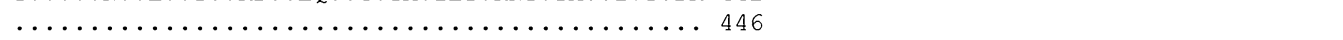 \\
\hline NC8 & plnc8K & $\begin{array}{c}\cdots \cdots \cdots \\
\cdots\end{array}$ \\
\hline Kcing & A sequeric & $\begin{array}{l}\text { e alignment of UL4HK with HPK of reported pInEF loci. Low amino acid sequence identity at N-terminal receptor doma } \\
\text { no acids that identical to UL4HK are represented by dot. }\end{array}$ \\
\hline
\end{tabular}

Bacteriocins with GG leader peptides were processed and secreted by a dedicated $\mathrm{ABC}$-transporter. A highly conserved secretion operon, either plnGHTUVW or plnGHSTUVW was found in those reported $p \ln E F$ loci. The major difference between $p \ln G H T U V W$ or $p \ln G H$ $S T U V W$ operon is that $p \ln T$ of $p \ln G H T U V W$ operon is a fusion gene of $p \ln S$ and $p \ln T$ of $p \ln G H S T U V W$ operon [28]. The secretion operon that detected in UL4-plnEF locus was plnGHTUVW operon. UL4-plnG and UL4$p \ln H$ encoded for a hybrid ABC-transporter and its corresponding accessory protein, respectively. This hybrid ABC-transporter consists of a $\mathrm{N}$-terminal proteolytic, a core trans-membrane spanning and a C-terminal ATPbinding domain. UL4-plnT appeared to be a fusion gene of $p \ln S$ and $p \ln T$ found in C11, WCFS1, J51, NC8 and J23. UL4-plnT shared 99.1 and $96.9 \%$ amino acid sequence identity to JDM1- and V90-plnT, respectively. The plnTUVW encoded putative proteins that belong to Abi family and they contained protease CAAX motif [55]. It was noted that some identified bacteriocin immunity proteins belong to Abi family and Kjos et al. [56] have shown the involvement of several Abi proteins in bacteriocin self-immunity $[28,57,58]$. However, the role of plnTUVW in bacteriocin system still remains unknown.

\section{Genetic location of $p / w$ and plnEF loci}

The genetic location of $p l w$ locus has not been reported elsewhere. However, plnEF locus of L. plantarum WCFS1 


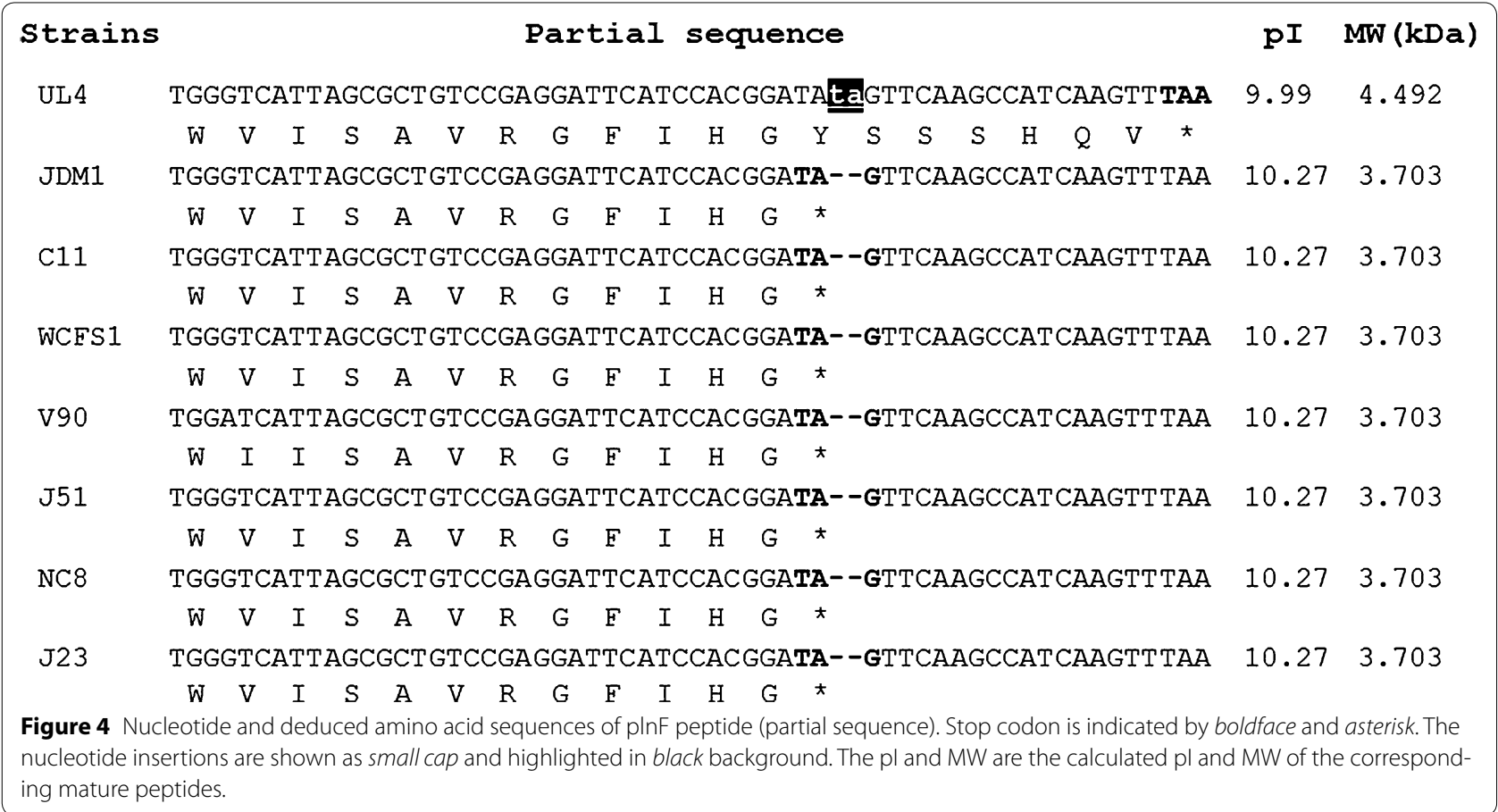

[23] and L. plantarum JDM1 [24] have been reported to be located on chromosomal DNA. L. plantarum I-UL4 that employed in this study harboured multiple plasmids as shown by agarose gel electrophoresis of the genomic DNA (Figure 5). Therefore, Southern hybridisation of genomic DNA with three DNA probes, namely $16 \mathrm{~S}_{\text {probe' }}$ $\mathrm{EF}_{\text {probe }}$ and $\mathrm{W}_{\text {probe, }}$ were carried out to determine the genetic location of UL4-plnEF and UL4-plw loci that harboured in L. plantarum I-UL4. The $16 \mathrm{~S}_{\text {probe }}$ generated in this study was $100 \%$ complementary to the $16 \mathrm{~S}$ rDNA sequence of L. plantarum I-UL4, which was specific to chromosomal DNA rather than plasmid DNA. The hybridisation signals generated by $16 \mathrm{~S}_{\text {probe }}$ would differentiate and confirm the identification of chromosomal DNA band from plasmid DNA bands separated by agarose gel electrophoresis. The hybridisation signal of $\mathrm{EF}_{\text {probe }}$ and $\mathrm{W}_{\text {probe }}$ were detected at the same DNA band as the $16 \mathrm{~S}_{\text {probe }}$ (Figure 5), indicating that plnEF and plw loci were located on chromosomal DNA since the location of $16 \mathrm{~S}$ rDNA is only found in chromosomal DNA of L. plantarum I-UL4.

\section{Conclusions}

L. plantarum I-UL4 was shown to be a multiple bacteriocin producer, harbouring $p l w$ and new mosaic $p \ln E F$ loci that chromosomally encoded as shown by Southern hybridisation. This is the first report of a L. plantarum strain harbouring the combination of $p l w$ and $p \ln E F$ loci concomitantly. The plantaricin $\mathrm{W}$ and plantaricin EF encoded by $p l w$ and $p \ln E F$ loci respectively are two different classes of bacteriocin, in which plantaricin $W$ is a class I bacteriocin molecule while plantaricin EF is a class II bacteriocin molecule. UL4-plw locus was highly conserved and contained remarkable amino acid sequence of LMG2379-plw locus. However, the UL4-plnEF locus appeared to be a composite pln locus of JDM1-plnEF and J51-plnEF locus in terms of genetic composition and organisation. The new genetic composition and organisation of $p \ln E F$ locus and concurrent presence of $p \ln E F$ and $p \ln W$ loci indicated that $L$. plantarum I-UL4 is a novel multiple bacteriocin producer that possesses vast potentials in various industries.

\section{Methods}

\section{Bacterial strain and culture conditions}

L. plantarum I-UL4 isolated from fermented tapioca, "tapai ubi" was used in this study [35]. The strain was deposited at the Microbial Culture Collection Unit (UNICC) of Institute of Bioscience, Universiti Putra Malaysia with deposition number UPMC5. The studied strain was grown in de Man-Rogosa-Sharpe (MRS) media (Merck, Germany) at $30^{\circ} \mathrm{C}$ [59] under anaerobic condition.

\section{Genomic DNA extraction}

The genomic DNA of L. plantarum I-UL4 was extracted using the method described by de los Reyes-Gavilán et al. [60] with minor modifications. Briefly, a single 


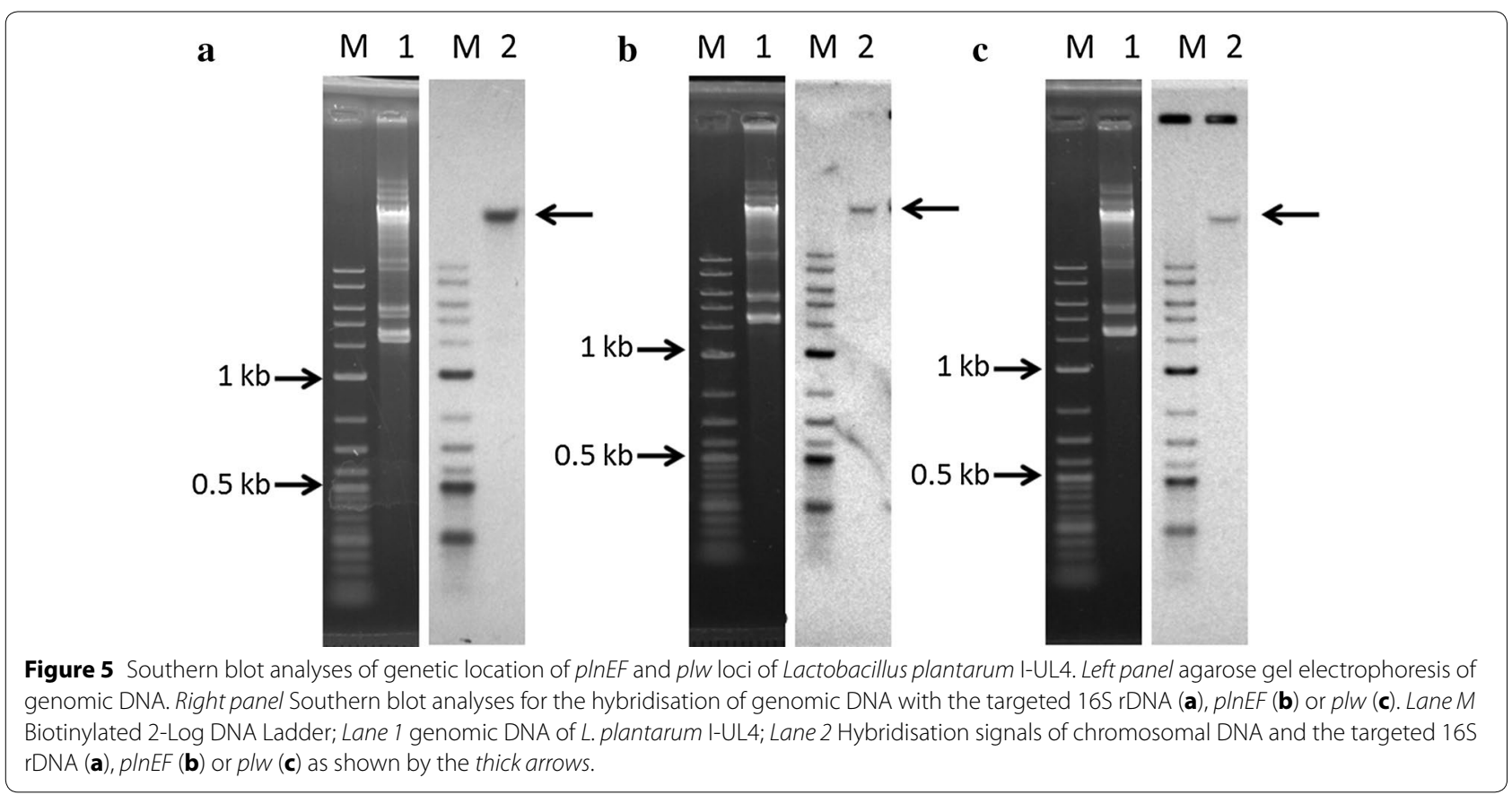

colony of L. plantarum 1-UL4 was inoculated into $10 \mathrm{ml}$ of MRS broth and incubated at $30^{\circ} \mathrm{C}$ for overnight. Bacteria cells were then harvested from $1 \mathrm{ml}$ of overnight culture by centrifugation at $16,000 \times g$ for $10 \mathrm{~min}$ at $4^{\circ} \mathrm{C}$, followed by incubating the cell pellet for $1 \mathrm{~h}$ at $37^{\circ} \mathrm{C}$ in $200 \mu \mathrm{l}$ of TEG buffer ( $25 \mathrm{mM}$ Tris- $\mathrm{HCl}, 10 \mathrm{mM}$ EDTA and $50 \mathrm{mM}$ glucose at $\mathrm{pH} 8.0)$ containing $15 \mathrm{mg} \mathrm{ml}^{-1}$ lysozyme (Sigma, USA). Subsequently, $100 \mu \mathrm{l}$ of $15 \%$ $(\mathrm{w} / \mathrm{v})$ SDS was added and mixed by gentle inversion to lyse the cells. Then, $300 \mu \mathrm{l}$ of $3 \mathrm{M}$ cold sodium acetate buffer ( $\mathrm{pH}$ 5.2) was added and the mixture was inverted gently, followed by incubation on ice for $5 \mathrm{~min}$. The mixture was then centrifuged at $16,000 \times g$ for $10 \mathrm{~min}$ at $4^{\circ} \mathrm{C}$ to precipitate the proteins. The resulting supernatant was transferred into a clean microcentrifuge tube and mixed with an equal volume of phenol:chloroform:isoa mylalcohol solution (Amresco, USA). After centrifugation at $16,000 \times g$ for $15 \mathrm{~min}$ at $4^{\circ} \mathrm{C}$, the aqueous phase containing DNA was transferred to a new microcentrifuge tube. Two sample volumes of cold absolute ethanol was then added to the aqueous phase, followed by gently mixing and incubated overnight at $-20^{\circ} \mathrm{C}$ to precipitate the DNA. The mixture was centrifuged at $16,000 \times g$ for $15 \mathrm{~min}$ at $4^{\circ} \mathrm{C}$ to collect the DNA after overnight incubation. DNA pellet was then washed with $1 \mathrm{ml}$ of $70 \%(\mathrm{v} / \mathrm{v})$ cold ethanol and air-dried in a laminar air flow before re-suspended in $40 \mu \mathrm{l}$ of $1 \times$ TE buffer (10 mM Tris$\mathrm{HCl}$ and $1 \mathrm{mM}$ EDTA at $\mathrm{pH}$ 7.0). RNA was removed by adding RNase A (Fermentas, Germany) to a final concentration of $0.4 \mathrm{mg} \mathrm{ml}^{-1}$, followed by incubation at $37^{\circ} \mathrm{C}$ for $15 \mathrm{~min}$.

\section{Detection of $p / n$ genes}

Gene-specific primers were designed specifically based on the published pln genes sequences selected randomly from plw [19], plS [20], pln423 [21] and $p \ln E F$ [22, 27] loci using internet-based software, PRIMER3 [61]. The specificity of each primer is listed in Table 3. PCR amplification was carried out in $25 \mu \mathrm{l}$ reaction mixture containing $1 \times$ Taq buffer, $0.2 \mu \mathrm{M}$ of each dNTPs, $2 \mathrm{mM}$ $\mathrm{MgCl}_{2}$ (Fermentas, Germany), $0.08 \mu \mathrm{M}$ of each forward and reverse primers, 1 unit of Taq DNA polymerase and $500 \mathrm{ng}$ of genomic DNA extracted from the studied strain. PCR reaction was performed with MyCycler $^{\text {тM }}$ Thermal Cycler (BioRad, USA) using following program: (a) initial denaturation at $95^{\circ} \mathrm{C}$ for $5 \mathrm{~min}$, (b) 30 cycles of denaturation at $95^{\circ} \mathrm{C}$ for $1 \mathrm{~min}$, (c) annealing at $53^{\circ} \mathrm{C}$ for $1 \mathrm{~min}$, (d) extension at $72^{\circ} \mathrm{C}$ for $1 \mathrm{~min}$, and (d) final extension at $72^{\circ} \mathrm{C}$ for $7 \mathrm{~min}$. PCR products were analysed using $1 \%(\mathrm{w} / \mathrm{v})$ agarose gel electrophoresis. Gradient PCR with annealing temperature of $50-60^{\circ} \mathrm{C}$ was carried out for primers that produced negative results. Two positive controls (PLANT1 and LOWLAC primers that specific to partial 16S rDNA of L. plantarum [62]) and a negative control (without DNA template) were included in PCR amplification to monitor the functionality of DNA template, PCR components and contamination. The positive controls produced specific PCR fragment of $996 \mathrm{bp}$. 
Table 3 PCR primers that designed for the detection of pln genes haboured in Lactobacillus plantarum I-UL4

\begin{tabular}{|c|c|c|c|c|}
\hline Target gene & Function & Primer sequence $\left(5^{\prime}-3^{\prime}\right)$ & Size (bp) & References \\
\hline \multirow[t]{2}{*}{ brnQ1 } & Amino acid transport protein & F: ATGCTCTTTGGGATGTTTTTT & 1,068 & [23] \\
\hline & & R: ACGATGAAATAGCGGTGAGG & & \\
\hline \multirow[t]{2}{*}{ napA1 } & $\mathrm{Na}-{ }^{+} / \mathrm{H}^{+}$antiporter & F: AAGTATTTACGCCCTGCCATTA & 798 & [23] \\
\hline & & R: TTAAACCCACACTGACGAAGAA & & \\
\hline \multirow[t]{2}{*}{ pln } & Prebacteriocin & F:TAACGACGGATTGCTCTG & 475 & [22] \\
\hline & & R: AATCAAGGAATTATCACATTAGTC & & \\
\hline \multirow[t]{2}{*}{ plnk } & Prebacteriocin & F: CTGTAAGCATTGCTAACCAATC & 246 & {$[22]$} \\
\hline & & R: ACTGCTGACGCTGAAAAG & & \\
\hline \multirow[t]{2}{*}{$p \ln L$} & Putative immunity protein & F:TAGATGCCGCTCCGTAAAGT & 442 & {$[22]$} \\
\hline & & R: CGTTACCCTCGCCAAAGTG & & \\
\hline \multirow[t]{2}{*}{$p \ln M$} & Unknown function & F:TGCTTGAAAGAATTACAGGATT & 171 & {$[22]$} \\
\hline & & R: CAAACGCAACCATCAAAATA & & \\
\hline \multirow[t]{2}{*}{$p \ln N$} & Prebacteriocin & F: ATTGCCGGGTTAGGTATCG & 146 & [22] \\
\hline & & R: CCTAAACCATGCCATGCAC & & \\
\hline \multirow[t]{2}{*}{ plnO } & Glycosyl transferase group 2 family & F: CGGAGACCCTTTATTATTTTG & 580 & {$[22]$} \\
\hline & & R:TCTTCGGACCCCTCTGATT & & \\
\hline \multirow[t]{2}{*}{$p \ln P$} & Protease CAAX family & F:TCCGAAAAGTATGGACAAATGA & 437 & {$[22]$} \\
\hline & & R: AAAGTTCCCCAAAGCAGACC & & \\
\hline \multirow[t]{2}{*}{$p \ln A$} & Induction factor & F: CAAATTAAAGGTATGAAGCAACT & 113 & [22] \\
\hline & & R:TTCTTTACCTGTTTAATTGCAG & & \\
\hline \multirow[t]{2}{*}{$p \ln B$} & Histidine kinase & F: CTGGCTTGTCGGAGTATGGT & 531 & [22] \\
\hline & & R: CGTCATTTAGGCTTGCTCTG & & \\
\hline \multirow[t]{2}{*}{$p \ln C$} & Response regulator & F: GGCGACAGGAGATTTACAAGA & 437 & [22] \\
\hline & & R: CCACTTTATTTTTGGCAGTCAG & & \\
\hline \multirow[t]{2}{*}{$p \ln D$} & Response regulator & F:TGAGGACAAACAGACTGGAC & 415 & [22] \\
\hline & & R: GCATCGGAAAAATTGCGGATAC & & \\
\hline \multirow[t]{2}{*}{ plnEF } & Prebacteriocin & F: GGCATAGTTAAAATTCCCCCC & 428 & [22] \\
\hline & & R: CAGGTTGCCGCAAAAAAAG & & \\
\hline \multirow[t]{2}{*}{$p|n|$} & Immunity & F: CGTTAATGGGTGATTGAGTTG & 424 & [22] \\
\hline & & R: AGTCTGCCTTTGAGCCTAGC & & \\
\hline \multirow[t]{2}{*}{ plnG } & $\mathrm{ABC}$ transporter & F:TGCGGTTATCAGTATGTCAAAG & 454 & {$[22]$} \\
\hline & & R: CCTCGAAACAATTTCCCCC & & \\
\hline \multirow[t]{2}{*}{ plnH } & Accessory protein & F: AGTTTTACGGGATTCGGTTT & 986 & [22] \\
\hline & & R: CTTTGCACCACGGTAATTGT & & \\
\hline \multirow[t]{2}{*}{$p / w$} & Prebacteriocin & F: AGTCGTCGTAAGAATGCTATTG & 389 & [19] \\
\hline & & R: TCACACGAAATATTCCA & & \\
\hline \multirow[t]{2}{*}{ plwG } & $\mathrm{ABC}$ transporter & F: GGTGTACTGGACTTAGGCATGG & 1,034 & [19] \\
\hline & & R: CGCTCTCGCAATCGTTATTC & & \\
\hline \multirow[t]{2}{*}{$p \ln C 8$} & Prebacteriocin & F: GGTCTGCGTATAAGCATCGC & 207 & [27] \\
\hline & & R: AAATTGAACATATGGGTGCTTTAAATTCC & & \\
\hline \multirow[t]{2}{*}{ pINC8HK } & Histidine kinase & F: AGCGGCAGTTATGGTAGGAC & 790 & [27] \\
\hline & & R: AATCCCTTTAGTTTGGGCATC & & \\
\hline plac & $\mathrm{ABC}$ transporter & F: GGCGTCTTTCTTGCTTTTG & 301 & [21] \\
\hline & & R: ACCCGTTGTTCCCATAGTC & & \\
\hline plaD & Accessory protein & F:TGGACTCAAAAATGGCACAA & 950 & [21] \\
\hline & & R: GGAACCACAACTAACGAGCA & & \\
\hline p/s & Prebacteriocin & F: GCCTTACCAGCGTAATGCCC & 320 & [20] \\
\hline & & R: CTGGTGATGCAATCGTTAGTTT & & \\
\hline $16 \mathrm{~S}$ rDNA & Positive control & PLANT1 : ATCATGATTTACATTTGAGTG & 996 & {$[62]$} \\
\hline & & LOWLAC: CGACGACCATGAACCACCTGT & & \\
\hline
\end{tabular}




\section{Amplification and characterisation of pln loci}

Primers were designed to analyse the upstream and downstream DNA sequences of pln genes (Table 4) amplified from L. plantarum I-UL4 genomic DNA. The PCR reaction mixture and program were as described in the experiment of "Detection of pln genes", but slightly longer time of 8 min was used for each extension cycle. The DNA Walking SpeedUp ${ }^{\text {tw }}$ Kit II (Seegene, Germany) was used to amplify the upstream and downstream DNA sequences of $p l n$ genes according to the manufacturer's recommendations when the reference DNA sequence was not available.

DNA sequence analysis of PCR amplified fragments

The PCR products were separated by $1 \%(\mathrm{w} / \mathrm{v})$ agarose gel electrophoresis. The desired DNA fragments were excised from the agarose gel using clean scalpel and purified by using Wizard ${ }^{\circ}$ SV Gel and PCR Clean-Up System (Promega, USA). The nucleotide sequence of the amplified fragments were analysed by ABI PRISM ${ }^{\mathrm{Tm}} 3730 \times 1$ DNA Analyzer using BigDye ${ }^{\circ}$ Terminator v3.0 Cycle Sequencing Kit performed by First Base Laboratories Sdn. Bhd. (Malaysia).

\section{DNA alignment and deduced amino acid sequence} analysis

The computer software, BioEdit version 7.0.5.2 [63] was used to process and assemble nucleotide sequences, to calculate the percentage identity of DNA and deduced amino acid sequences and to perform the alignment of multiple sequences. ORF-Finder program (http://www. ncbi.nlm.nih.gov/gorf/), GeneMark [64] and Glimmer [65] were then used to determine ORF. Similarity search of nucleotide sequence was performed using Basic Local Alignment Search Tool (BlastN) program (http://blast. ncbi.nlm.nih.gov/). DNA sequence located at the upstream of start codon of each ORF was searched for the putative ribosomal binding site (RBS) manually by comparing the reported DNA sequence of RBS (5'-AGGAGG-3, which is complementary to $3^{\prime}$ end of $16 \mathrm{~S}$ rRNA $5^{\prime}$ CCUCCU-3') of L. plantarum [66]. Putative promoter was also searched manually by comparing amplified DNA sequence with promoter sequences reported for pln operons [28]. Isoelectric point (pI) and molecular mass (MW) of the deduced peptide were calculated using ExPASY Compute pI/MW program (http://expasy.org/tools/pi_tool.html) and conserved protein domains were identified using CDsearch program (http://www.ncbi.nlm.nih.gov/Structure/ cdd/wrpsb.cgi) available at NCBI website.

\section{Determination of genetic location of $p / n$ loci}

Southern hybridisation was carried out to determine the genetic location of $p \ln$ loci that harboured $p \ln E F$
Table 4 PCR primers that designed for the upstream and downstream DNA sequence amplification of PCR amplified pln genes harboured in Lactobacillus plantarum I-UL4

\begin{tabular}{|c|c|}
\hline Primer designation & Primer sequence $\left(5^{\prime}-3^{\prime}\right)$ \\
\hline \multirow[t]{2}{*}{ brnQ1-napA1 } & F: ATGCTCTTTGGGATGTTTTT \\
\hline & R: ACGATGAAATAGCGGTGAGG \\
\hline \multirow[t]{2}{*}{ napA1-L } & F: GTGGGCTTGAGTGGTGCTAT \\
\hline & R:TACTTTACGGAGCGGCATCT \\
\hline \multirow[t]{2}{*}{ R-plnD } & F: AGCAGCCCCATCACTAATC \\
\hline & R: AACATCTTTGGGCTGACTATT \\
\hline \multirow[t]{2}{*}{ plnD-1 } & F:TGAGGACAAACAGACTGGAC \\
\hline & R: AGTCTGCCTTTGAGCCTAGC \\
\hline \multirow[t]{2}{*}{ plnl-EF } & F: CGTTAATGGGTGATTGAGTTG \\
\hline & R: CACGGATATAGTTCAAGCCATC \\
\hline \multirow[t]{2}{*}{ plnEF-G } & F: CGGTCACGCAAAACTAGAAAT \\
\hline & R: TCAATCACCGCTTGTAAGAAA \\
\hline \multirow[t]{2}{*}{ plnG-H } & F:TTATTGGCGGTTTTAGGTCA \\
\hline & R: CGCGCACCTTCAACTAAATA \\
\hline \multirow[t]{2}{*}{ plwG1 } & F: CGGAATGTGGACTTTGTTGT \\
\hline & R:TGCTGGCTTCCATTATTTCA \\
\hline \multirow[t]{2}{*}{ brnQ1-walk } & F: CCAAGGGGGTCTTTGTAGGT \\
\hline & R: CCAAAGTCGCACAAGTCAGTA \\
\hline \multirow[t]{2}{*}{ plnU-helicase } & F: ATTTTGAGATGCCAGTCCTGTT \\
\hline & R:TGGTCGCATACGATGTCTCC \\
\hline \multirow[t]{2}{*}{ Plw } & F: CGCTTGCCAATGAACAAATA \\
\hline & R: CGCCAATCGGGAATTTATCA \\
\hline \multirow[t]{3}{*}{ plwGTSP } & F1: AGATGAGGCGACTAGCAGTGT \\
\hline & F2: GGTGAAAATTTGAGAAAGGACAG \\
\hline & F3:TGTAGCACATCGACTATCAACCA \\
\hline
\end{tabular}

$F$ forward primer, $R$ reverse primer.

and $p l w$ structural genes were either chromosomally or plasmid encoded. Genomic DNA of L. plantarum I-UL4 was separated by $0.7 \%(\mathrm{w} / \mathrm{v})$ agarose gel electrophoresis and visualized by UV transillumination. The separated genomic DNA bands were then depurinated, denatured and transferred onto the Immobilon-Ny+ Transfer Membrane (Milipore, USA) according to the instructions of manufacturer. Three DNA probes of $16 \mathrm{~S}_{\text {probe }}, \mathrm{EF}_{\text {probe }}$ and $\mathrm{W}_{\text {probe }}$ that developed from PCR products generated from primers listed in Table 1 were labelled using the NEBlot ${ }^{\bullet}$ Phototope $^{\circ}$ Kit (New England Biolabs, USA) according to the manufacturer's instruction. The probes were $100 \%$ specific to $16 \mathrm{~S}$ rDNA [62], plnEF [22] structural gene and $p l w$ [19] structural gene of L. plantarum I-UL4, respectively. The Southern blot membrane containing separated genomic DNA bands of L. plantarum I-UL4 was prehybridised with DNA probes at $58^{\circ} \mathrm{C}$ for $40 \mathrm{~min}$, followed by further hybridisation at $53^{\circ} \mathrm{C}$ for $18 \mathrm{~h}$. The hybridised membrane was then processed and visualised further using Phototope $\mathrm{e}^{\circ}$-Star Detection Kit 
(New England Biolabs, USA) performed according to the manufacturer's instruction.

\section{End note}

The DNA sequences for both plw and plnEF loci of L. plantarum I-UL4 were deposited at [GenBank/ EMBL/DDBJ with accession numbers of GU322921 and GU138149] respectively.

\section{Abbreviations}

pln: plantaricin; ORF: open reading frame; RBS: ribosomal binding site; IF: induction factor; HPK: histidine protein kinase; RR: response regulator; pl: isoelectric point; MW: molecular mass.

\section{Authors' contributions}

HFT carried out the molecular characterisation study of pln genes, participated in the sequence alignment and drafted manuscript. HLF participated in the design, conceived and coordination of this study; and helped to draft and revised the manuscript. RAR participated in the design of the study and sequence alignment. TCL participated in the design of the study and helped to draft the manuscript. MPA participated in the design of the study and the sequence alignment. KY participated in the molecular characterisation study of p/n genes. All authors read and approved the final manuscript.

\section{Author details \\ ${ }^{1}$ Department of Bioprocess Technology, Faculty of Biotechnology and Bio- molecular Sciences, Universiti Putra Malaysia, 43400 UPM Serdang, Selangor, Malaysia. ${ }^{2}$ Institute of Bioscience, Universiti Putra Malaysia, 43400 UPM Serdang, Selangor, Malaysia. ${ }^{3}$ Department of Cell and Molecular Biology, Faculty of Biotechnology and Biomolecular Sciences, Universiti Putra Malaysia, 43400 UPM Serdang, Selangor, Malaysia. ${ }^{4}$ Department of Animal Science, Faculty of Agriculture, Universiti Putra Malaysia, 43400 UPM Serdang, Selangor, Malaysia. ${ }^{5}$ Institute of Tropical Agriculture, Universiti Putra Malaysia, 43400 UPM Serdang, Selangor, Malaysia. ${ }^{6}$ Department of Biofunctional Chemistry, Graduate School of Environmental and Life Sciemce, Okayama University, Okayama, Japan.}

\section{Acknowledgements}

This work was supported by the Long-Term Research Grant Scheme (LRGS) granted by the Ministry of Education Malaysia.

\section{Compliance with ethical guidelines}

\section{Competing interests}

The authors declare that they have no competing interests.

Received: 1 May 2015 Accepted: 2 June 2015

Published online: 16 June 2015

\section{References}

1. Ray B, Bhunia A (2008) Fundamental food microbiology, 4th edn. CRC Press, New York

2. Piard JC, Desmazeud M (1991) Inhibition factors produced by lactic acid bacteria: Oxygen metabolites and catabolism end products. Le Lait 71:525-541

3. Piard JC, Desmazeud M (1992) Inhibiting factors produced by lactic acid bacteria: bacteriocins and other antibacterial substances. Le Lait 72:113-142

4. Tagg JR, Dajani AS, Wannamaker LW (1976) Bacteriocins of Gram-positive bacteria. Bacteriol Rev 40:722-756

5. Sablon E, Contreras B, Vandamme E (2000) Antimicrobial peptides of lactic acid bacteria: mode of action, genetics and biosynthesis. Adv Biochem Eng Biotechnol 68:21-60

6. Hechard Y, Sahl HG (2002) Mode of action of modified and unmodified bacteriocins from Gram-positive bacteria. Biochemie 84:545-557

7. Bauer R, Dicks LMT (2005) Mode of action of lipid Il-targeting lantibiotics. Int J Food Microbiol 9:201-206
8. Hoover DG, Chen H (2005) Bacteriocins with potential for use in foods. In: Davidson PM, Sofos JN, Branen AL (eds) Antimicrobials in food, 3rd edn. CRC Press, New York, pp 389-428

9. Gillor O, Nigro LM, Riley MA (2005) Genetically engineered bacteriocins and their potential as the next generation of antimicrobials. Curr Pharm Des 11:1065-1075

10. Gillor O, Etzion A, Riley MA (2008) The dual role of bacteriocins as antiand probiotics. Appl Microbiol Biotechnol 81:591-606

11. Galvez A, Abriouel H, Lopez RL, Omar NB (2007) Bacteriocin-based strategies for food biopreservation. Int J Food Microbiol 120:51-70

12. Dimov S, Ivanova P, Harizanova N (2005) Genetics of bacteriocins biosynthesis by lactic acid bacteria. Biotechnol Biotechnol Equip 19:4-10

13. Klaenhammer TR (1993) Genetics of bacteriocins produced by lactic acid bacteria. FEMS Microbiol Rev 12:39-86

14. Smaoui S, Elleuch L, Bejar W, Karray-Rebai I, Ayadi I, Jaouadi F et al (2010) Inhibition of fungi and Gram-negative bacteria by bacteriocin BacTN635 produced by Lactobacillus plantarum sp. TN635. Appl Biochem Biotechnol 162:1132-1146

15. Todorov SD, Nyati H, Meincken M, Dicks LMT (2007) Partial characterisation of bacteriocin AMA-K, produced by Lactobacillus plantarum AMA-K isolated from naturally fermented milk from Zimbabwe. Food Control 18:656-664

16. Todorov SD, Dicks LMT (2005) Lactobacillus plantarum isolated from molasses produces bacteriocins active against Gram-negative bacteria. Enzyme Microbial Technol 36:318-326

17. Todorov SD, Dicks LMT (2004) Influence of growth conditions on the production of a bacteriocin by Lactococcus lactis subsp. lactis ST34BR, a strain isolated from barley beer. J Basic Microbiol 44:305-316

18. Messi P, Bondi M, Sabia C, Battini R, Manicardi G (2001) Detection and preliminary characterisation of a bacteriocin (plantaricin 35d) produced by a Lactobacillus plantarum strain. Int J Food Microbiol 64:193-198

19. Holo H, Jeknic Z, Daeschel M, Stevanovic S, Nes IF (2001) Plantaricin W from Lactobacillus plantarum belongs to a new family of two-peptide lantibiotics. Microbiology 147:643-651

20. Stephens SK, Floriano B, Cathcart DP, Bayley SA, Witt VF, Jiménez-Díaz R et al (1998) Molecular analysis of the locus responsible for production of plantaricin S, a two-peptide bacteriocin produced by Lactobacillus plantarum. Appl Environ Microbiol 64:1871-1877

21. van Reenen CA, Chikindas ML, Van Zyl WH, Dicks LMT (2003) Characterisation and heterologous expression of a class lla bacteriocin, plantaricin 423 from Lactobacillus plantarum 423, in Saccharomyces cerevisiae. Int J Food Microbiol 81:29-40

22. Diep DB, Havarstein LS, Nes IF (1996) Characterisation of the locus responsible for the bacteriocin production in Lactobacillus plantarum C11. J Bacteriol 178:4472-4483

23. Kleerebezem M, Boekhorst J, van Kranenburg R, Molenaar D, Kuipers OP, Leer R (2003) Complete genome sequence of Lactobacillus plantarum WCFS1. Proc Natl Acad Sci 100:1990-1995

24. Zhang ZY, Liu C, Zhu YZ, Zhong Y, Zhu YQ, Zheng HJ et al (2009) Complete genome sequence of Lactobacillus plantarum JDM1. Genome Announc 191:5020-5021

25. Rojo-Bezares B, Sáenz Y, Navarro L, Jiménez-Díaz R, Zarazaga M, Ruiz-Larrea F et al (2008) Characterisation of a new organisation of the plantaricin locus in the inducible bacteriocin-producing Lactobacillus plantarum J23 of grape must origin. Archiv Microbiol 189:491-499

26. Navarro L, Rojo-Bezares B, Saenz Y, Diez L, Zarazaga M, Ruiz-Larrea F et al (2008) Comparative study of the pln locus of the quorum-sensing regulated bacteriocin-producing L. Plantarum J51 strain. Int J Food Microbiol 128:390-394

27. Maldonado A, Ruiz-Barba JL, Jimenez-Diaz R (2003) Purification and genetic characterisation of plantaricin NC8, a novel coculture-inducible two-peptide bacteriocin from Lactobacillus plantarum NC8. Appl Environ Microbiol 69:383-389

28. Diep DB, Straume D, Kjos M, Torres C, Nes IF (2009) An overview of the mosaic bacteriocin pln loci from Lactobacillus plantarum. Peptides 30:1562-1574

29. Loh TC, Thanh NT, Foo HL, Bejo MH, Azhar BK (2010) Feeding of different levels of metabolite combinations produced by Lactobacillus plantarum on growth performance, fecal lactic acid bacteria and Enterobacteriaceae count, volatile fatty acids and villi height in broilers. J Anim Sci 81:205-214 
30. Loh TC, Chong SW, Foo HL, Law FL (2009) Effects on growth performance, faecal microflora and plasma cholesterol after supplementation of spraydried metabolite to postweaning rats. Czech J Animal Sci 54:10-16

31. Loh TC, Harun HA, Foo HL, Law FL (2008) Effects of feeding spray-dried metabolites of Lactococcus lactis subsp. lactis-RW18 in post-weaning rats. Int J Probiotics Prebiotics 3:1-6

32. Loh TC, Lee TM, Foo HL, Law FL, Rajion MA (2008) Growth performance and fecal microflora of rats offered metabolites from lactic acid bacteria. J Appl Animal Res 34:61-64

33. Thanh NT, Loh TC, Foo HL, Bejo MH, Azhar BK (2009) Effects of feeding metabolite combinations produced by Lactobacillus plantarum on growth performance, faecal microbial population, small intestine villus height and faecal volatile fatty acids in broilers. Br Poult Sci 50:298-306

34. Foo HL, Loh TC, Law FL, Lim YS, Kufli CN, Rusul G (2003) Effect of feeding Lactobacillus plantarum I-UL4 isolated from Malaysian Tempeh on growth performance, faecal flora and lactic acid bacteria and plasma cholesterol concentrations in postweaning rats. Food Sci Biotechnol 12:403-408

35. Lim YS (2003) Master thesis. Universiti Putra Malaysia, Malaysia

36. Thanh NT, Loh TC, Foo HL, Bejo MH, Kasim AB (2010) Inhibitory activity of metabolites produced by strains of Lactobacillus plantarum isolated from Malaysian fermented food. Int J Probiotics Prebiotics 5(1):37-43

37. Moghadam MS, Foo HL, Leow TC, Raha AR, Loh TC (2010) Novel bacteriocinogenic Lactobacillus plantarum strains and their differentiation by sequence analysis of $16 \mathrm{~S}$ rDNA, 16S-23S and 23S-5S intergenic spacer regions and randomly amplified polymorphic DNA analysis. Food Technol Biotechnol 48:476-483

38. Omar NB, Abriouel H, Lucas R, Martinez-Canamero M, Guyot JP, Galvez A (2006) Isolation of Bacteriocinogenic Lactobacillus plantarum strains from ben saalga, a traditional fermented gruel from Burkina Faso. Int J Food Microbiol 112:44-50

39. Omar NB, Abriouel H, Keleke S, Sanchez Valenzuela A, Martinez-Canamero M, Lucas Lopez R et al (2008) Bacteriocin-producing Lactobacillus strains isolated from poto poto, a Congolese fermented maize product, and genetic fingerprinting of their plantaricin operons. Int J Food Microbiol 30:18-25

40. Knoll C, Divol B, du Toit M (2008) Genetic screening of lactic acid bacteria of oenological origin for bacteriocin encoding genes. Food Microbiol 25:983-991

41. Risoen PA, Havarstein LS, Diep DB, Nes IF (1998) Identification of the DNA-binding sites for two response regulators involved in control of bacteriocin synthesis in Lactobacillus plantarum C11. Mol Gen Genet 259:224-232

42. Risoen PA, Brurberg MB, Eijsink VGH, Nes IF (2000) Functional analysis of promoters involved in quorum sensing-based regulation of bacteriocin production in Lactobacillus. Mol Microbiol 37:619-628

43. Risoen PA, Johnsborg O, Diep DB, Hamoen L, Venema G, Nes IF (2001) Regulation of bacteriocin production in Lactobacillus plantarum depends on a conserved promoter arrangement with consensus binding sequence. Mol Genet Genomics 265:198-206

44. Axelsson L, Holck A (1995) The genes involved in production of and immunity to Sakacin A, a bacteriocin from Lactobacillus sake Lb706. J Bacteriol 177:2125-2137

45. Diep DB, Axelsson L, Grefsli C, Nes IF (2000) The synthesis of the bacteriocin sakacin $A$ is a temperature-sensitive process regulated by a pheromone peptide through a three-component regulatory system. Mircobiology 146:2155-2160

46. Huhne K, Axelsson L, Holck A, Krockel L (1996) Analysis of the sakacin P gene cluster from Lactobacillus sake LB674 and its expression in sakacinnegative Lb. sake strains. Microbiology 142:1437-1448

47. Eijsink VGH, Brurberg MB, Middelhoven PH, Nes IF (1996) Induction of bacteriocin production in Lactobacillus sake by a secreted peptide. J Bacteriol 178:2232-2237

48. Franz CMAP, van Belkum MJ, Worobo RW, Vederas JC, Stiles ME (2000) Characterisation of the genetic locus responsible for production and immunity carnobacteriocin A: the immunity gene confers cross-protection to enterocin B. Microbiology 146:621-631

49. Quadri LEN, Kleerebezem M, Kuipers OP, de Vos WM, Stiles ME (1997) Characterisation of a locus from Carnobacterium piscicola LV17B involved in bacteriocin production and immunity: evidence for global inducermediated transcriptional regulation. J Bacteriol 179:6163-6167
50. Nilsen T, Nes IF, Holo H (1998) An exported Inducer peptide regulates bacteriocin production in Enterococcus faecium CTC492. J Bacteriol 180:1848-1854

51. O'Keeffe T, Hill C, Ross RP (1999) Characterisation and heterologous expression of the genes encoding enterocin A production, immunity, and regulation in Enterococcus faecium DPC1146. Appl Environ Microbiol 65:1506-1515

52. Diep DB, Havarstein LS, Nes IF (1995) A bacteriocin-like peptide induces bacteriocin synthesis in Lactobacillus plantarum C11. Mol Microbiol 18:631-639

53. Kleerebezem M, Kuipers OP, de Vos WM, Stiles ME, Quadri LEN (2001) A two-component signal-transduction cascade in Carnobacterium piscicola LV17B: two signaling peptides and one sensor-transmitter. Peptides 22:1597-1601

54. Havarstein LS, Holo H, Nes IF (1994) The leader peptide of colicin V shares consensus sequences with leader peptides that are common among peptide bacteriocins produced by Gram-positive bacteria. Microbiology 140:2383-2389

55. Pei J, Grishin NV (2001) Type II CAAX prenyl endopeptidases belong to a novel superfamily of putative membrane-bound metalloproteases. Trends Biochem Sci 26:275-277

56. Kjos M, Snipen L, Salehian Z, Nes IF, Diep DB (2010) The Abi proteins and their involvement in bacteriocin self-immunity. J Bacteriol 192:2068-2076

57. Datta V, Myskowski SM, Kwinn LA, Chiem DN, Varki N, Kansal RG et al (2005) Mutational analysis of the group A streptococcal operon encoding streptolysin $\mathrm{S}$ and its virulence role in invasive infection. Mol Microbiol 56:681-695

58. LuxT, Nuhn M, Hakenbeck R, Reichmann P (2007) Diversity of bacteriocins and activity spectrum in Streptococcus pneumonia. J Bacteriol 189:7741-7751

59. de Man JC, Rogasa M, Sharpe ME (1960) A medium for the cultivation of lactobacilli. J Appl Bacteriol 23:130-135

60. de los Reyes-Gavilán CG, Limsowtin GK, Tailliez P, Sechaud L, Accolas JP (1992) Lactobacillus helveticus-specific DNA probe detects restriction fragment length polymorphisms in this species. Appl Environ Microbiol 58:3429-3432

61. Rozen S, Skaletsky HJ (2000) Primer3 on the WWW for general users and for biologist programmers. Methods Mol Biol 132:365-386

62. Chagnaud P, Machinis K, Coutte LA, Marecat A, Mercenier A (2001) Rapid PCR-based procedure to identify lactic acid bacteria: application to six common Lactobacillus species. J Microbiol Methods 44:139-148

63. Hall TA (1999) BioEdit: a user-friendly biological sequence alignment editor and analysis program for Windows 95/98/NT. Nucleic Acids Symp Ser 41:95-98

64. Lukashin A, Borodovsky M (1998) GeneMark.hmm: new solutions for gene finding. Nucleic Acids Res 26:1107-1115

65. Delcher AL, Bratke KA, Powers EC, Salzberg SL (2007) Identifying bacterial genes and endosymbiont DNA with Glimmer. Bioinformatics 23:673-679

66. Pouwels PH, Leer RJ (1993) Genetics of lactobacilli: plasmids and gene expression. Antonie Van Leeuwenhoek 64:85-107

\section{Submit your next manuscript to BioMed Central and take full advantage of:}

- Convenient online submission

- Thorough peer review

- No space constraints or color figure charges

- Immediate publication on acceptance

- Inclusion in PubMed, CAS, Scopus and Google Scholar

- Research which is freely available for redistribution

Submit your manuscript at

www.biomedcentral.com/submit
C Biomed Central 